Zagadnienia Rodzajów Literackich, LX, z. 2

PL ISSN 0084-4446

DOI: $10.26485 / Z R L / 2017 / 60.2 / 3$

Justyna DąbKowska-Kujko

Katolicki Uniwersytet Lubelski Jana Pawła II*

\title{
Dawny apoftegmat. Między historią, retoryką a filozofią
}

\author{
The Old Apothegm: between History, Rhetoric and Philosophy
}

\begin{abstract}
This article is devoted to the apothegm understood as a literary genre. The aim of the article is to present the etymology of the very word as well as gather and organize the distinctive features of the genre by referring to the Greek, Roman and early modern tradition in order to highlight those aspects that indicate its evolution. What is more, the article also points out the differences between the apothegm and other cognate genres, such as proverbs, maxims, gnomes, dicta, anecdotes and aphorisms. The apothegm is presented as an exceptional genre since, by emphasizing the conciseness and wit of "speech activities", it enhances sensitivity to current circumstances. Aptly, the apothegm strengthens a singular, wittily articulated and highly individual verbal reaction to a situation that occurred at an exceptional moment.

The article especially points to the philosophical aspect of the apothegm, that is, its anthropological dimension. The apothegm is the form of the word, capable of expressing all intricacies of human nature, becoming an equivalent to history or biography. Thus approaching apothegm, that is, as a literary genre, allows it to be considered as an adequate reflection of one's personality, combining the constant with the singular and the changeable in human nature. Therefore, the genre borders on rhetoric, history, biography and philosophy.
\end{abstract}


* Instytut Filologii Polskiej, Katedra Historii Literatury Staropolskiej Wydział Nauk Humanistycznych Katolickiego Uniwersytetu Lubelskiego al. Racławickie 14, 20-950 Lublin e-mail: justdab@kul.lublin.pl 
Słowna prezentacja mądrości jawi się dziś jako zasadniczy fenomen greckiej kultury, a apoftegmat jest jej najdobitniejszym wyrazem; wyznaczywszy dość niewielki obszar pragmatyce jednostkowych działań, gatunek ów w planie pierwszym sytuuje znakomite powiedzenia, charakterystyczne wypowiedzi (egregie dicta) ${ }^{1}$. Jest to jedna z najstarszych i zarazem najbardziej powszechnych (obok przysłów, maksym, gnom, sentencji, anegdot i aforyzmów) genologicznych form „sapiencjalnych”, która w zewnętrznej prostocie przekazu, czasem w żartobliwej dykcji, w stylu „niskim” acz wytwornym, znalazła metodę wyrażania i recypowania nierzadko najwznioślejszych etycznie treści. Jest to zarazem jeden z chętniej wykorzystywanych gatunków literatury filozoficznej. Apoftegmaty, na ogół imiennie przypisywane znanym osobistościom, gromadzono w zamkniętych zbiorach, będących rejestrem zwięzłych, trafnych i błyskotliwych wyrażeń; wykorzystywano je też w innych formach piśmiennictwa zwykle o silnym dydaktycznym i wychowawczym nacechowaniu, np. w funkcji egzemplarycznej jako ogniwo w retorycznym procesie argumentacji. W przeciwieństwie jednak do wyżej wymienionych form pokrewnych (tj. przysłów, maksym, gnom, sentencji, anegdot, aforyzmów) gatunek ów nie jest narzędziem przekazywania mądrości powszechnej, tradycyjnej, środowiskowo nieraz warunkowanej, którą odbiorca w pewnym sensie podziela z autorem. Mądrość apoftegmatu to mądrość — by tak się wyrazić — nacechowana indywidualizmem, wyrażona bystro i kreatywnie w celu przekazania mniej lub bardziej ważnych treści prowokowanych sposobną chwila.

Znany jest fakt, iż to Grecy w szczególności przyczynili się do stworzenia rozległej tradycji kumulowania i przechowywania sądów oraz powiedzeń sławnych jednostek, składanych następnie w zbiorowej pamięci i przekazywanych przez wieki ustnie, zanim w erze poklasycznej powstały mniej lub bardziej uporządkowane rejestry tego rodzaju literatury. Do najbardziej znanych kolekcji należą prace Plutarcha i Diogenesa Laertiosa, choć trzeba zarazem pamiętać o jawnych antycypacjach tej tradycji w dużo wcześniejszych pismach

1 Tak też za pisarzami antycznymi Erazm z Rotterdamu określał zbiory apoftegmatów, zob. Erasmus, Ep. 2431,6-7; wszystkie odsyłacze do korpusu listów Erazma (skrót Ep.) za: Desiderius Erasmus Roterodamus (1906-1958), Opus epistolarum, 12 voll., denuo recognitum et auctum per P.S. Allen, M.H. Allien, H.W. Garrod, in typographeo Clarendoniano, Oxonii. Por. też Erasmus, Adagia (proleg:), [w:] Desiderius Erasmus Roterodamus (1703-1706), Opera omnia, ex recensione Ioannis Clerici, Pieter van der Aa, Lugduni Batavorum, vol. 2: 2E, 3F, 4C. 
Herodota czy Ksenofonta. Na kolekcje lakońskich powiedzeń chętnie też powoływał się Arystoteles w Retoryce (II 211394 a-1395 b) — musiały więc już istnieć za jego czasów - przyznając im dużą wartość intelektualną oraz moc urabiania moralnych postaw. Do popularyzacji tego typu wypowiedzi przyczynił się jednak najbardziej wspomniany już Plutarch. Powiedzenia królów i wodzón oraz Powiedzenia spartańskie — dzieła chyba najintensywniej eksplorowane w dobie nowożytnej, skarbnica egzemplów zwłaszcza dla włoskich (Antonio Beccadelli, Poggio Bracciolini, Lodovico Domenichi, Baptista Fregoso, Angelo Poliziano, Domenicio Nani Mirabelli, Paolo Manuzio, Lucio Domizio Brusoni itd.), niemieckich (m.in. Conrad Lycosthenes, Joseph Lange) i niderlandzkich (np. Justus Lipsius, Jan Gruter) kompilatorów apoftegmatów, facecji i sentencji, nieocenione źródło pism Erazma z Rotterdamu — są właśnie śladem utrwalania takiej oralnej tradycji epickich recytacji czy odtwarzania jej ze świadectw bardziej zamierzchłej przeszłości. Podczas gdy jednak ta odległa przeszłość, wraz z jej legitymizacją mitu i heroicznych legend, mogła cieszyć się najwyższym prestiżem i leżeć wyłącznie w sferze podziwu niedosiężnej naśladownictwu, źródłowo dająca się udokumentować era historyczna oferowała paradygmatyczne egzempla — bliskie i użyteczne w procesie modelowania codziennych obyczajów. W tym ostatnim przypadku apoftegmat stawał się przedmiotem cytatów i przekształceń bądź obiektem wielokrotnych wykorzystań, zbliżał się tym samym w swej funkcji do gnomy, maksymy czy przysłowia, jak ma to miejsce w odniesieniu do wielu apoftegmatów filozofów, przywoływanych w dziele Laertiosa. Zarazem jednak fakt owych zbliżeń może posłużyć jako argument, że pierwotna natura apoftegmatu pozostaje różna od wymienionych gatunków „sapiencjalnych”.

Rzymianie oczywiście podzielają upodobanie do owych form, stając się nie tylko dziedzicami tradycji apoftegmatycznej, ale także jej godnymi kontynuatorami. I tak z dzieł Kwintyliana (Inst. orat. 6,3,5) i Makrobiusza (Sat. 2,1,12) wiemy, że Cyceron miał kolekcję apoftegmatów, zebraną w trzech tomach; z kolei z przekazu Cycerona (ad fam. 9,16,4) oraz świadectwa Swetoniusza (Iul. 56) wynika, że takie zbiory gromadził również Gajusz Cezar. Literackim zaś punktem dojścia kolekcjonerskiej fascynacji Rzymian tym gatunkiem jest zbiór Factorum et dictorum memorabilium libri novem Waleriusza Maksymusa, drugiego po Plutarchu autora chętnie wykorzystywanego przez europejskich humanistów, konstytuującego wraz z Grekiem nowożytną konwencję exemplum virtutum, charakterystyczną dla moralizującej retoryki wszystkich zresztą czasów. W dziele Waleriusza jednak apoftegmat spleciony jest już wyraźnie z anegdotą, ukierunkowany jest zatem na narrację, stając się domeną zarazem czynów i słów jako świadectwem zrealizowanej etyki.

Autorytet apoftegmatu wyrósł z podłoża greckiej myśli retorycznej i filozoficznej, w szczególny sposób dowartościowującej słowo oraz siłę jego oddziaływania i wszelkie formy werbalnej prezentacji mądrości, z bystrymi powiedzeniami na czele. Autorami ich były znaczące indywidualności, artykułujące je w jakimś niespodziewanym czy ważnym, z nagła się zdarzającym momencie, tj. w czasie, dla którego Grecy znaleźli specjalne określenie kairos (gr. xaıós). Jest to kategoria czasu, w najprostszym ujęciu oznaczająca stosowny moment lub okazję. Z filozoficznego zaś punktu widzenia określa ona krótką, szybką, ulotną czy doniosłą chwilę; jest pojęciem odsyłającym do czasu (w przeciwieństwie do kategorii

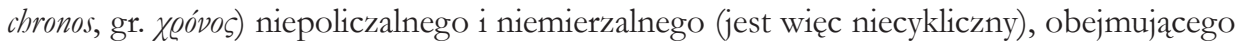
udział jednostek i zdarzeń. Kairós to więc czas pojawiający się jako swego rodzaju wyłom czy pęknięcie na linii innej kategorii — chronos; to czas, którego — zauważa Krzysztof 
Bielawski — „linearność, ciągłość i prostota uległy jakiemuś zaburzeniu i tym samym zyskały walor wyjątkowości, niezwykłości i niepowtarzalności. To kairos jest tym czasem, który »nadchodzi«; równocześnie nigdy nie powraca” (Bielawski 2014: 67; Smith 1969: 1-13).

W świetle tych uwag apoftegmat jawi się jako gatunek szczególny, będący świadectwem — by tak się wyrazić - eksplozji kairos. Utrwala on bowiem jednostkowa, bystro wyartykułowaną i silnie zindywidualizowaną reakcję słowną na sytuację zaistniałą w czasie, pojętym właśnie jako mgnienie, chwila charakteryzująca się jaką́s wyjątkową cechą, pozwalająca na wyodrębnienie jej z monotonii czasu linearnego. Apoftegmat to forma prezentująca jednostki wyróżniające się darem rozpoznawania swych „kairosów”; to gatunek nimi kipiący; zupełnie wyjątkowy, bo akcentując celność, zwięzłość i błyskotliwość reakcji słownych, dowartościowuje perfekcyjne wyczucie wobec bieżących okoliczności.

Wiara w autorytarną moc słowa (logos) zarówno w retoryce, jak i w obszarze filozofii oraz literatury antycznej była tak powszechnie dzielona i akceptowana, że nie wymagała jakichś osobnych deklaracji, uzasadnień czy obrony. Dość przypomnieć, że sami sofiści, przyznający słowu szczególną siłę, chętnie porównywali retorykę do sztuki walki (zob. np. świadectwo Platona w: Gorgiasz 456c-d; Eutydem, 272a i nast.), umożliwiającej zwycięstwo w specyficznie pojętym politycznym, sądowym czy prywatnym ,agonie na słowa” (Laertios 1982: 546 IX 8,52; por. Nerczuk 2011: 57-58). Gorgiasz z Leontinoi w Pochwale Heleny wyrażał przekonanie, że w logosie upatrywać należy „wielkiego mocarza”, który swoim nie dającym się zobaczyć ciałem wpływa na ludzi, urabiając ich sądy (Gorgiasz 1984: 4-5); był on nawet pewien, że moc słowa jest tak wielka, iż da się ją zrównać z przemoca fizyczna. Inny sofista, Protagoras z Abdery, został uznany przez Diogenesa Laertiosa za tego, który jako pierwszy w retoryce „wyłożył moc kairos”, dowodząc, iż od okoliczności zależy, czy dany pogląd jest (pragmatycznie bądź relatywnie) prawdziwy, czy też nie (Laertios 1982: 546 IX 8,52; por. Nerczuk 2011: 57-58)². Platon zaś w Gorgiaszu (451d) pisał, że retoryka jest najwyższą ze sztuk, opanowanie zasad perswazji w dowolnej dziedzinie prowadzi bowiem do osiagnnięcia największego dobra ${ }^{3}$.

Nie dysponujemy dziś wieloma materiałami konstytuującymi teorię apoftegmatu czy omawiającymi jego genologiczne principia. Do tych nielicznych należy wypowiedź Plutarcha, który uzasadniając użyteczność tego rodzaju kolekcji, wyakcentował kilka aspektów gatunku. Otóż we wstępie do swego zbioru Powiedz̨enia królów i wodzón, w słowach kierowanych do rzymskiego cesarza Trajana, a wyraźnie nawiązujących do tego, co Platon w Protagorasie (342e-343b) rzekł ustami Sokratesa na temat kultury lakońskiej, tj. spartańskiej zdolności tworzenia zwięzłych i celnych sformułowań, których miłośnikami oraz dziedzicami okazało się siedmiu mędrców greckich ${ }^{4}$, pisał (172c-e):

2 Koncepcja kairos znana była zatem starożytnej retoryce. W szczególności odwoływał się do niej Gorgiasz, choć w ogóle była chętnie wykorzystywana w sofistyce greckiej. Miała się ona wyrażać w dostosowaniu mowy do bieżących okoliczności. Gorgiasz sądził, że „skuteczność retoryczna polega na mówieniu odpowiednich rzeczy w odpowiednim momencie (kairos), dlatego niektórzy twierdzą, że był on pierwszym mistrzem relatywistycznej etyki sytuacyjnej, która nie ma nic wspólnego z etyką normatywną opartą na niepodważalnych zasadach. Na pewno uważał, że skuteczność człowieka wynika z umiejętności dostosowania się do sytuacji i wymagań chwili. Tę umiejętność musi posiadać każdy dobry mówca” (Mielczarski 2011: 16). Zob. też Routledge History of Philosophy 1997: 235; Kennedy 1963: 66-67.

3 Wykorzystano tu uwagi Z. Nerczuka (zob. 2011: 57, przyp. 30).

4 „(...) którzy zeszli się razem i z pierwocin swojej mądrości ofiarę złożyli Apollonowi, wypisując w świątyni delfickiej to, co przecież wszyscy wyśpiewują: »Poznaj siebie samego«i »Niczego ponad miarę»" (Platon 1958). 
(...) przynoszę Ci oto skromne dary i podarunki, będące znakiem przyjaźni, oraz powszechne pierwociny filozofii [aparchaí apó philosophias - J.D.-K.], abyś przyjął wraz z moją gorliwością również pożytek płynący z tych powiedzeń, o ile mogą się one przyczynić do poznania charakterów i skłonności władców, które wszak wyraźniej ukazują się poprzez słowa niż czyny. Masz wprawdzie także Żywoty, pisma traktujące o najsłynniejszych władcach Rzymian i Hellenów, prawodawcach i cesarzach, jednakże w wielu czynach kryje się domieszka losu, tymczasem wypowiedzi i słowa, towarzyszące działaniom, doznaniom czy kolejom losu, dają sposobność ujrzenia jak najwyraźniej, niczym w zwierciadle, myśli każdej z owych osób. Tak też Pers Sejramnes ludziom dziwiącym się, że mimo iż słowa jego są rozsądne, to dziełom nie towarzyszy powodzenie, odrzekł, że oto władcą słów jest on sam, panem czynów zaś — los i król. Zamieszczone tam [tj. w Żywotach - J.D.-K.] wypowiedzi mężów, z dołączonymi opisami ich czynów, wymagają oprócz chęci lektury również wolnego czasu, a zebrane tutaj [tj. w przypisanym cesarzowi zbiorze apoftegmatów - J.D.-K.] same tylko słowa, będące zaledwie próbkami i zalążkami żywotów, nie staną się — jak sądzę — obciążeniem dla Twego czasu, a przy tym podane w zwięzłej formie umożliwią $\mathrm{Ci}$ wnikliwe zapoznanie się $\mathrm{z}$ wieloma godnymi pamięci postaciami. (Plutarch 2006: 34)

Usłyszeliśmy tu osobliwą (bo nieuwzględniającą społecznej, kontekstualnej, dialogowej i interaktywnej natury słownych wypowiedzeń, rezygnującą też z oddania pełni aktywności człowieka) teorię słów, znajdujących się niejako w opozycji wobec czynów. Plutarch wyjaśnia bowiem, że ethos (moralna postawę) i idee polityczne wielkich historycznych postaci najlepiej można rozpoznać i zrozumieć, analizując nie ich czyny, lecz wypowiedziane przez nich słowa. Ludzkie działania są wszakże powiązane z sytuacja zewnętrzna, ich rezultat — zależny od losu, podczas gdy słowa — niezdeterminowane, wolne od tego rodzaju koneksji — znajdują się pod zupełną kontrolą człowieka i dlatego stanowią najbardziej wiarygodne świadectwo jego myśli oraz są miarodajnym znacznikiem skłonności i charakteru. Potrzebował Plutarch takiej koncepcji, by wyrazić swą zasadniczą tezę dotyczącą słowa wypowiadanego świadomie, będącego własnością człowieka, świadectwem jego sprawności intelektualnej i niejako jego obrazem, autonomizującego się wobec nieobliczalnej siły losu. Zauważmy na marginesie, że z punktu widzenia tej antropologicznej koncepcji (a chciałoby się też rzec — psycholingwistycznej) logos przejmuje te własności, które w teoriach etycznych przypisywane były virtus. Ten optymistyczny w istocie sąd na temat człowieczej kontroli nad własnym językiem i języka jako probierza charakteru, zwierciadła duszy czy umysłu daje przesłanki wiodące do wyostrzenia sensu filozoficznego, a zarazem rozpoznania psychologicznie pojętej kategorii kairos (jako okazji do ujawnienia szczególnego rodzaju mądrości, świadomie i trzeźwo bowiem artykułowanej w zwięzłych oraz trafnie wyrażonych słowach). Uprzytamnia zarazem, jak wielka jest skuteczność tak rozumianego języka oraz w jaki sposób można go użyć jako strategii czy raczej narzędzia społecznego istnienia człowieka — by tak powiedzieć — „poprzez mowę”.

Mimo iz apoftegmaty były swobodnie przytaczane przez pisarzy greckich, okazują się gatunkiem dość trudnym w procesie definiowania jego istotnych cech. Etymologicznie rzecz ujmując, apophthegma (przedrostek ámo- plus rzeczownik $\varphi \theta \dot{z} \gamma \gamma o \mu a \imath$ ) sugeruje zarówno znaczenie: „wypowiedź”, „powiedzenie”, jak i odmienny sens — „riposta”. Większość starożytnych apoftegmatów cytowanych jest właśnie głównie w funkcji bystrych powiedzeń przywoływanych w kontekście krótkich opowiadań, przy czym ów kontekst ma znaczenie ewidentnie wtórne. Badania przeprowadzone przez współczesnych uczonych nad użyciem tego terminu na przestrzeni wielu stuleci uświadamiaja jednak, że w starożytnej 
Grecji termin apophthegma zawierał pewną dwuznaczność, stopniowo zmieniając swoje semantyczne centrum. Wiele bowiem wskazuje, że pierwotnie oznaczał on właśnie ripostę, a więc ważny był dla niego kontekst, z którego wywodziło się powiedzenie. Z czasem dopiero znaczenie terminu przesunęło się w kierunku bardziej ogólnego pojęcia „rzeczenie", przez co apoftegmat stał się synonimem sentencji, maksymy bądź gnomy (tak już w dziele Diogenesa Laertiosa). Ostatecznie powstało znaczenie terminu najbardziej chyba oddalone od pierwotnego sensu, apoftegmat bowiem stał się zaledwie odpowiednikiem anegdoty, dowcipnej historyjki, facecji, co zresztą znajduje swoje racjonalne uzasadnienie w fakcie, iż z natury był on osadzony w krótkiej historii. Tak też rozumieli go staropolscy pisarze renesansowi ${ }^{5}$, spadkobiercy włoskich zwłaszcza tradycji facecjonistycznych, na czele z: Łukaszem Górnickim, parafrazującym w 1566 roku Castiglionowego Il Cortegiano, bezimiennym twórcą Facecji polskich (ok. 1570), odtwarzającym pomysły Boccaccia i Domenichiego, czy Bieniaszem Budnym (Krótkie a wezłowate opowieści, które po grecku zowa Apoftegmata, Wilno 1599), imitującym co prawda Plutarchowy zbiór, wyraźnie jednak przetwarzającym go w kierunku moralistycznych narracji, anegdot i historii. Z pewnością również Rej (Figliki, 1562 oraz Apoftegmata, 1568) i Kochanowski (Apoftegmata, wydane pośmiertne we Fragmentach, 1590) łączyli go z krótkim opowiadaniem: pierwszy wiodąc apoftegmat w kierunku abstrakcyjnych wywodów aretologicznych (Budzyńska-Daca 2005: 159-170), drugi — zwięzłej narracji, wolnej często od moralnej wykładni i wychowawczych intencji, w ingenium za to lokującej czynnik najwyższej wartości.

Najwcześniejsze użycie i rozumienie terminu apoftegmat znaleźć można u Ksenofonta (zob. np. Hellenika 2,3,56), a potem Arystotelesa (zob. wyżej). Wyraźnie pojmowali go oni jako bystre powiedzenie, którego trafność polega na najwyższym stopniu uwrażliwienia na specyficzny kontekst; a zatem chodzi o odpowiedź pojęta jako reakcja na zaistniałe zdarzenie bądź usłyszane słowa czy o swego rodzaju sumację opisanej sytuacji. W II w. po Chrystusie rozumienie Plutarcha zdaje się być wciąż bliskie znaczeniu „riposta”, przeważająca bowiem większość przywołanych przez niego apoftegmatów to wypowiedzenia, których sens został wyprowadzony z kontekstu (nawet jeśli ów kontekst pełni całkiem „techniczną” rolę, jest więc wtórny). Jakkolwiek znaleźć tu już można kilka przykładów, w których miejsce żywej reakcji zajmuje po prostu wypowiedź lub słowna artykulacja jakichś stwierdzeń (postanowień, rozstrzygnięć). Są w końcu i cytaty, będące świadectwem znamiennego przesunięcia od tego, co zostało powiedziane przez jednostkę, w kierunku tego, co zostało opisane przez narratora, stąd należałoby właściwiej nazwać je anegdotami niż apoftegmatami. Zawierają one bowiem już nie tyle godne pamięci powiedzenia, ile raczej godne pamięci incydenty, opowiedziane w formie historii, kładącej nacisk na czyny, historii mającej przecież naturę raczej „zdarzeniową” niż „słowną”. Znaczyłoby to, że dla Plutarcha apoftegmatem może być zarówno bystra reakcja słowna domagająca się kontekstu, jak i „sapiencjalne” powiedzenie obywające się bez godnych przytoczenia uwag wstępnych ${ }^{6}$.

Próbę definicji apoftegmatu w jego aplikacjach staropolskich podjęła T. Michałowska, zob. Michałowska 1990: 41-42. Zob. też m.in.: Stěpán 2012: 46; Krzyżanowski 1958: 24-25; Krzyżanowski 1960: 5-21; Graciotti 1991: 185-203.

6 Zreferowano tu ustalenia J. Russo (zob. 1997: 57-64). 
Semantyczne parametry greckiego apoftegmatu nie będą wszakże pełne, jeśli nie uwzględnimy jeszcze jednego aspektu: gatunek ów bowiem doraźną sytuację nierzadko ujmował w ramy metaforycznego powiedzenia, wiodąc tym samym ku alegorii rozumianej jako mówienie obrazowe, zawierające jakąś ukrytą aluzję. Demetriusz w swych uwagach poświęconych stylowi $(99,151)^{7}$, opisując rodzaj sądu, który określa jako alegorię, ilustruje swój wywód tymi samymi słowami Dionizjusza Starszego, których Arystoteles — przypisując je jednak Stezychorosowi - użył w Retoryce do omówienia apoftegmatu (Arystoteles 2001: 403 II 21 1395a), pojmowanego jako mowa podobna do lakońskiej, której sens z racji swej enigmatyczności domaga się wykładni. Wiele zatem wskazuje na to, że apoftegmat nie tylko dzielił się na dwie kategorie: dosłowny, artykułujący treści wprost, oraz alegoryczny, przenośny, wyrażający myśli w obrazowej formie zagadki, potrzebujący zatem swego rodzaju egzegezy (zob. Russo: 1997: 63-64), lecz również trwale i od początku głównie ze względu na swa pełną znaczenia zwięzłość i trafność ujęć — zbliżał się do gnomy, sentencji i przysłowia, bądź wpleciony w narrację — przyjmował postać anegdoty.

To, co starożytni mówili o apoftegmatach jako formach fascynujących głębią i „kompendialnością", urzekających dowcipem, objawianym w prędkich i celnych reakcjach na „dar okazji”, co mieli do powiedzenia o nich jako „zalążkach filozofii” i „odpryskach” dawnej mądrości, dużo później Erazm rzekł również o adagiach i prowerbiach. Zdaniem Rotterdamczyka bowiem formy te cechuja się z jednej strony (zewnętrznej) prostota, z drugiej (wewnętrznej) charakterem enigmatycznym, co w efekcie przybliża je do paraboli, należącej w gruncie rzeczy do dziedziny alegorii, w której ostatecznie humanista ujrzał misteryjny wymiar słowa:

(...) Arystoteles u Synezjusza wyraża przekonanie, że przysłowia to nic innego jak resztki owej pradawnej filozofii, wymarłej wskutek niepomyślnych kolei spraw ludzkich, i że zachowały się one po części z powodu swojej sumaryczności i krótkości [ob compendium brevitatemque], po części z powodu swego dowcipu i wdzięku [ob festivitatem ac leporem], toteż nie trzeba ich leniwie i niedbale oglądać z wierzchu, lecz wnikać w nie pilniej i głębiej, kryją się w nich bowiem jakby iskierki dawnej mądrości, która w dociekaniu prawdy o wiele bardziej będzie przenikliwa, niż byli późniejsi filozofowie. Podobnie Plutarch w rozprawie, której nadał tytuł Jak naleşy casytá poetów, twierdzi, że starożytne adagia przypominają żywo misteria religijne, w których pewne wzniosłe i boskie rzeczy wyraża się zazwyczaj za pomocą całkiem błahych i na pozór nieomal śmiesznych obrzędów. Albowiem w tych tak krótkich powiedzeniach jakby przez zasłonę daje się do zrozumienia to samo, co monarchowie filozofii przekazali w tylu woluminach (Erasmus, Adagia [proleg.], vol. 2: 6C-F; cyt. za: Domański 2001: 250-251)

Zbiory apoftegmatów zatem jako „pierwocin filozofii” oraz „próbek i zalążków żywotów”, będące wyrazem bystrej czy trzeźwej reakcji umysłu w tym wyjątkowym momencie, kiedy chronos załamuje się w kairos, świadectwem niezwykłego daru artykulacji sądów w zwięzłej i trafnej formule, wreszcie domeną ludzkiego ducha, wizerunkiem intelektu i obrazem wewnętrznej formacji człowieka, który poprzez słowo, głoszone dogmata konkretyzuje się jako godny podziwu, są galerią osobowości znanych z przeszłości, cieszących się uznaniem, osobowości widzianych na skrzyżowaniu dróg historii i biografii, filozofii i retoryki. Drogi te spotykają się właśnie w „sumarycznej” naturze apoftegmatu, gatunku zdającego się jednak wyraźnie marginalizować podmiotowy i czynny wymiar humanizmu, 
tak silnie akcentowany przez Cycerona, Kwintyliana oraz stoików, na rzecz entuzjazmu dla dziedziny słów. Jeśli jednak zarazem przypomnimy sobie, że słowo traktowane jest tu w jego antropologicznej pełni, tj. w zgodzie z platońską teorią mowy, będącej obrazem osobowości, mowy mającej moc ujawniania ludzkiej natury, i z koncepcją myślenia jako rodzaju konwersacji człowieka z samym sobą, zrozumiemy, że tak pojęte słowo, będąc swego rodzaju ekwiwalentem czy lepiej — ekstraktem duchowej sfery człowieka i dlatego niemal z nim identyczne, nabiera wymiaru podmiotowego; mając zaś moc przekształcania rzeczywistości i budowania międzyludzkich relacji, staje się niemal równorzędne wobec czynu, jeśli nie z nim tożsame. Animus in oratione relucet pisał za antycznymi mistrzami Erazm w dziele Lingua i posłużył się Sokratesowym apoftegmatem, przywołując go oraz objaśniając jego sens za Florida Apulejusza:

Et in nobis animi speculum est oratio. Unde celebratur illud a Socrate dictum: "Loquere ut te videam《. Adductus erat adolescens elegante forma, ut ex aspectu colligeret indolem. At ille non videbat adolescentem, donec taceret, quod non tam in vultu, quam in oratione reluceat animus.

[„,I u nas zwierciadłem duszy jest mowa. Stąd sławne jest owo powiedzenie Sokratesa: »Przemów, abym cię mógł zobaczyć«. Przyprowadzono mu młodzieńca szlachetnej urody, aby z wyglądu ocenił jego charakter. Atoli on nie widział młodzieńca, póki ten milczał, bo dusza się odzwierciedla nie tyle w obliczu, ile w mowie']. (Desiderius Erasmus Roterodamus 1526: k. 60v.) ${ }^{8}$

W przedmowie zaś, jaką opatrzył swoje Apophthegmata, przy okazji pochwały etycznie profilowanego pisarstwa Plutarcha jako autora apoftegmatycznych kolekcji, Rotterdamczyk zauważał:

Maja (...) apoftegmaty swoją własną metodę i własny swój charakter, polegający na tym, że krótko, zręcznie, dowcipnie i wytwornie wyrażają wewnętrzną naturę człowieka. (Erasmus, Ep. 2431,57-59; przekł. pol. za: Domański 2001: 259)

Wyrażanie osobowości, krótkość oraz wytworny dowcip wskazane tu jako konstytutywne cechy gatunku, zostały ostatecznie przez humanistę podniesione do rzędu najwyższej wartości etycznej w słowach przyznających greckiemu mistrzowi range „świętości” 9

Apoftegmat zatem, będąc domeną słowa wyrażającego istotę ludzkiej natury, stał się gatunkiem uświadamiającym, jak bardzo mowa wpływa na intersubiektywne uzewnętrznianie się cech człowieka, a zastępując niejako potrzebę pisania historii czy biografii, albo raczej — zwalniając z tej potrzeby, sam niemal stał się ich miniaturowym ekwiwalentem. Skoro bowiem wartość apoftegmatu jako gatunku literackiego wyraża się w jego zdolności stania się adekwatnym wizerunkiem osobowości, to trzeba zarazem zaznaczyć, że miał

8 Przekład za: Domański 2001: 258. Por. APUL. Florida 2: At non itidem maior meus Socrates, qui cum decorum adulescentem et diutule tacentem conspicatus foret, «ut te videam - inquit - aliquid et loquere». Scilicet Socrates tacentem bominem non videbat; etenim arbitrabatur homines non oculorum, sed mentis acie et animi obtutu considerandos (przekł. J. D.-K.: „I nie w jednakowym stopniu jest większy mój Sokrates, który, gdy miał poznać pięknego, ale milczącego przez długi czas młodzieńca, rzekł: »Powiedz coś, abym cię zobaczył«. To znaczy, że Sokrates milczącego człowieka nie widział, był bowiem zdania, że ludzi powinno się oceniać nie poprzez spojrzenie, ale po oszacowaniu umysłu i wejrzeniu w duszę").

9 Pisał o nim (Ep. 2431,89-91): ,żaden wśród greckich pisarzy nie był bardziej święty i bardziej godny czytania” (cyt. za: Domański 2001: 259). Por. też Erasmus Ep. 2431,66-67 oraz tenże Adagia (proleg.), vol. 2: 5D. 
on wyrażać osobowość historyczną, nie zaś fikcyjną - mityczną bądź fantastyczną, miał odsyłać do konkretnie pojętego człowieka, nie zaś do abstrakcyjnych cnót, miał konstytuować egzemplum historyczne, nie topiczne. Spajając tym samym ze sobą to, co w wizerunku ludzkiego indywiduum - mimo jego uwarunkowania przez czas i otoczenie — stałe, mające charakter powszechny, z tym, co w nim prawdziwie zindywidualizowane, niepowtarzalne, wielorakie i zmienne, zbiory apoftegmatów sytuują się na pograniczu historii, biografii i filozofii. Ujęte w sekwencje powiedzenia historycznie skonkretyzowanych jednostek, ujawniając złożoną naturę osobowości, zarazem znajdowały swoje miejsce w systemie moralnym, stawały się jego częściami, zyskując tym samym znaczenie paradygmatu ${ }^{10}$. Inaczej rzecz ujmując: apoftegmat to forma, w której zmienna i złożona osobowość w perspektywie filozofii moralnej konstytuuje się jako uniwersalny wzór; w której sprowokowane okazją incydentalne powiedzenie zamknięte zostaje w swoiste egzemplum, dające się wydobyć z continumm czasu i wielości zwykłych słów oraz zawiłości dziejów; w którym zwięzłość, bystrość i trafność zyskują rangę etyczną; w którym wreszcie horyzont syntagmatyczny, tj. horyzont nieskończonych cech osobowych, których wielorakość i złożoność można wciąż odkrywać i nigdy do końca nie rozpoznać, poprzez swe spotkanie z założeniami filozofii moralnej przyjmuje cechy horyzontu paradygmatycznego jako obraz niezmiennej natury człowieka. Coś jednak zarazem odróżnia egzemplum od gatunkowo pojętego apoftegmatu: o ile bowiem intencja pierwszego, z jego prymatem tego, co ogólne i akcentem na wykładnię moralna, jest nawoływanie zwłaszcza do imitatio, o tyle drugiego (prócz słabo zresztą akcentowanego naśladownictwa) — zwłaszcza osąd, charakterystyka, prezentacja zindywidualizowanych postaw. Tak oto zbiory apoftegmatów, widziane jako zamknięta kompozycyjnie całość, będące rejestrem zdarzeniowo na ogół potraktowanych powiedzeń najznamienitszych osobowości minionego czasu, kumulują cały ogrom jednostkowych zróżnicowań charakterologicznych, konstytuując razem coś, co można by nazwać jako „indywidualność powszechna”, w której ostatecznie ma się wyrażać to, co w człowieku, z punktu widzenia aksjologii humanistycznej, najbardziej wartościowe - męstwo, prawość, przemyślność, trafność, odpowiedniość, rozsądek i bystrość.

Wszystkie te uwagi na temat genologicznych uwarunkowań apoftegmatu pozwalaja zrozumieć późniejszą wielką karierę tego gatunku w piśmiennictwie humanistycznym; albo szerzej: umożliwiaja zaobserwowanie, nie tylko jak silna i jak ważna dla humanistycznej tradycji filozoficznej jest refleksja nad słowem i jak różne może ona przyjać w literaturze formy, ale również pozwalają ocenić trwałość tej tradycji, dostrzec jej ciagłość i wypróbować jej prawdziwość na piśmienniczym materiale renesansu europejskiego, w szczególny sposób dowartościowującego drobne, „kompendialne” formy literackie, będące manifestacją roli i siły oraz społecznej skuteczności człowieczej mowy. Trzeba chyba w nich widzieć nie tylko ogniwo retorycznej, lecz może nade wszystko antropologicznej refleksji, która następnie — zagarnięta i przekształcona przez konceptystyczny barok przesunie swe centra ku fascynacji specyficznie pojejtym czasem, jako polem realizacji ludzkiego ingenium, rozumem ludzkim, „dowcipem”, fenomenem prędkości kojarzenia, sytuując tym samym apoftegmatyczne formy bardziej już po stronie retoryki niż filozofii, estetyki niż etyki.

10 Zob. inspirujące uwagi na temat roli apoftegmatu w twórczości Erazma Domański 2001: 225-263. 
„Stosować się do czasu” — to idea zgodnie przyznawana przez pisarzy humanistycznych najznamienitszym, z tym, że o ile w XVI stuleciu była ona raczej utożsamiana z prawdziwą mądrością, rozumiana jako okruch niebieskiego porządku, którego obrazem na ziemi jest natura, a którego wyrazem winno być życie prywatne człowieka rozumnego oraz życie towarzyskie i społeczne, o tyle w kolejnej epoce idea czynienia sobie czasu powolnym już nie tylko akcentowała pragmatycznie i etycznie ujmowany kunszt rozumu, ale przede wszystkim wydobywała estetyczny, by nie rzec — „narcystyczny” fenomen talentu, umiejętność będącą darem przyrodzenia:

Pioruny były pewnym orężem — pisał Gracián — którego zażywał bajeczny Jowisz, gdy chciał
w jednym momencie pokazać moc swoję nad śmiertelnemi. Tym orężem pokonał zbuntowa-
nych olbrzymów, albowiem prędkość matka jest rychłych sukcesów. Orzeł, który z bystrym
lotem wzbija się aż pod słońce, nosił pioruny Jowisza; ten zaś minister bożka grzmotu jest wy-
obrażeniem wielkich dowcipów, którym wspaniałość i obrotna prędkość w przedsięwziętych
dziełach jest przyzwoita. (Gracián 1765: 158-159)

Apoftegmat powoli, lecz wyraźnie ustępował miejsca maksymie w takim kształcie, jakim oczarował całą Europe François de La Rochefoucauld jako autor Maksym i rozważán moralnych (1665).

\section{Bibliografia}

Arystoteles (2001), Retoryka, przeł., wstępem i koment. opatrzył H. Podbielski [w:] tegoż, Drieła wszystkie, t. 6, PWN, Warszawa.

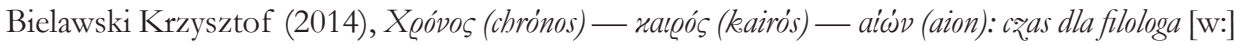

Boska radość powtórzenia. Idea wiecznego powrotu, red. M. Proszak, A. Szklarska, A. Żymełka, Wydawnictwo UJ, Kraków.

Budzyńska-Daca Agnieszka (2005), „Apoftegmata” — międyy oralnościq a piśmiennościq. Rozważania nad Rejowa nanka o cnocie [w:] Mikołaj Rej - w pié́setlecie urodzin, cz. 1, praca zb., red. J. Okoń, przy współpracy M. Bauera, M. Kurana i M. Mieszek, Wydawnictwo UŁ, Łódź. Demetriusz (1953), O wyrażaniu sie [w:] Tray stylistyki greckie: Arystoteles, Demetriusそ, Dionizjusz, przeł. i oprac. W. Madyda, Zakład Narodowy im. Ossolińskich, Wrocław.

Desiderius Erasmus Roterodamus (1526), Lingua, H. Vietor, Cracoviae.

- (1703-1706), Opera omnia, 10 voll., ex recensione Ioannis Clerici, Pieter van der Aa, Lugduni Batavorum (repr. Hildesheim 1961-1962).

- (1906-1958), Opus epistolarum, 12 voll., denuo recognitum et auctum per P.S. Allen, M.H. Allien, H.W. Garrod, in typographeo Clarendoniano, Oxonii.

Laertios Diogenes (1982), Żywoty i poglady stynnych filozofów, przeł. I. Krońska, K. Leśniak, W. Olszewski, B. Kupis, opracowanie przekładu, przypisy i skorowidz I. Krońska, wstęp K. Leśniak, PWN, Warszawa. 
Domański Juliusz (2001), Erazm i filozofia. Studium o koncepcji filozofii Erazma z. Rotterdamu, Fundacja Aletheia, Warszawa.

Gorgiasz (1984), Pochwała Heleny, przeł. K. Tuszyńska, „Przegląd Humanistyczny”, nr 3, R. 28. Gracián Baltasar (1765), Człowiek uniwersalny, przeł. z franc. P. Brzostowski, w drukarni J. K. M. Ks. Bazylianów, Wilno.

Kennedy George A. (1963), The Art of Persuasion in Greece, Princeton UP, Princeton.

Krzyżanowski Julian (1958), W wieku Reja i Stańçykea. Szkice z dziejów odrodzenia w Polsce, PWN, Warszawa.

— (1960), Facecja staropolska [w:] Dawna facecja polska (XVI-XVIII w.), oprac. J. Krzyżanowski i K. Żukowska-Billip, PIW, Warszawa.

Michałowska Teresa (1990), Apoftegmat [hasło w:] Stownik literatury staropolskiej (Średniowiecze - Renesans - Barok), red. T. Michałowska, przy udziale B. Otwinowskiej, E. Sarnowskiej-Temeriusz, Zakład Narodowy im. Ossolińskich, Wrocław.

Mielczarski Cyprian (2011), Dziedzictwo klasycznej sofistyki i kultura wspótczesna, „Forum Artis Rhetoricae", nr 3.

Nerczuk Zbigniew (2011), Żywot Protagorasa u Diogenesa Laertiosa (,Żywoty i poglady stynnych filozofów”, IX,50-56), „Studia Antyczne i Mediewistyczne”, nr 9 (44).

Platon (1958), Protagoras, przeł., wstępem, obj. i ilustr. opatrzył W. Witwicki, PWN, Warszawa. Plutarch (2006), Powiedzenia królów i wodzón [w:] tegoż, Powiedzenia królów i wodzón. Powiedzenia spartańskie, przeł., wstępem i obj. opatrzyła K. Jażdżewska, Prószyński i S-ka, Warszawa.

Routledge History of Philosophy (1997), vol. 1: From the Beginning to Plato, ed. C.C.W. Taylor, Routledge Taylor and Francis Group, London-New York.

Russo Joseph (1997), Prose Genres for the Performance of Traditional Wisdom in Ancient Greece: Proverb, Maxim, Apothegm [in:] Poet, Public, and Performance in Ancient Greece, ed. by L. Edmunds, R.W. Wallace, with a Preface by M. Bettini, The Johns Hopkins UP, Baltimore-London. Sante Graciotti (1991), Polska facecja bumanistyczna i jej włoskie wzorce [w:] tegoż, Od Renesansu do Oswiecenia, t. 1, PIW, Warszawa.

Smith John E. (1969), Time, Times, and the 'Right Time'; Chronos and Kairos, „The Monist”, nr 1(53). Štěpán Ludvik (2012), Apoftegmat, przeł. Leszek Engelking, [hasło w:] Stownik rodzajów i gatunków literackich. Nowe wydanie, red. G. Gazda, PWN, Warszawa. 